\title{
A Sweet and Painful Emotional Experience: Love Metaphors from a Cross-Cultural Perspective
}

\author{
Didi $\mathrm{Li}^{1} \&$ Daojia $\mathrm{Chi}^{2}$ \\ ${ }^{1}$ Tashkent State University of Uzbek Language and Literature, Tashkent, Uzbekistan \\ ${ }^{2}$ Faculty of Chinese Studies, Tashkent State University of Oriental Studies, Tashkent, Uzbekistan \\ Correspondence: Didi Li, Tashkent State University of Uzbek Language and Literature, Tashkent, Uzbekistan. \\ E-mail: lididigongzhu@gmail.com
}

Received: July 26, $2020 \quad$ Accepted: August 28, $2020 \quad$ Online Published: September 7, 2020

doi:10.5539/ijel.v10n6p137 URL: https://doi.org/10.5539/ijel.v10n6p137

\begin{abstract}
More and more researchers have begun to study the conceptual metaphor from the perspective of cognitive linguistics, and to connect the metaphor with language, culture and people's lives. The Emotional metaphor is an important aspect of cognitive linguistics, and love is an important emotion shared by all human beings. The study is an attempt to examine and compare how metaphorical expressions of love are employed in the texts of English and in the Chinese literary texts. The findings show that several love metaphors are shared in English texts and in Chinese literary texts that are based on common cognitive experiences. However, although many other different cultures also influence the linguistic expressions related to love metaphors, this study identifies specific love metaphors unique to English texts and to Chinese literary texts.
\end{abstract}

Keywords: cognitive linguistics, conceptual metaphor, love metaphors

\section{Introduction}

The "metaphor is pervasive in everyday life, not just in language, but in thought and in action. Our ordinary conceptual system, in terms of which we both think and act, is fundamentally metaphorical in nature" (Lakoff \& Johnson, 1980, p. 3). Metaphors are so ordinary that we use them unconsciously and automatically while we often fail to notice them (Lakoff \& Turner, 1989, p. 1). The primary function of the metaphor is to understand difficult, abstract, complex or less delineated concepts (Lakoff \& Johnson, 1980, p. 59). It can be seen that the metaphor, as a cognitive phenomenon and way of thinking, is an important means for humans to understand the world and concepts. The cognitive view of the metaphor holds that the essence of metaphor is a systematic and corresponding structural mapping between two concepts. Metaphors can systematically correspond one conceptual domain to another conceptual domain through human cognition and reasoning, that is, the metaphor is a conceptual mapping from a source domain to a target domain (Lakoff \& Johnson, 1980, p. 5; Lakoff \& Turner, 1989, p. 3; Kövecses, 2000, p. 5).

Based on the Conceptual Metaphor Theory (Lakoff \& Johnson, 1980, p. 3; Lakoff, 1993, pp. 202-251), emotional metaphors have become one of the best researched domains (Kövecses, 1986, 2000, 2005, pp. 35-47, 2015, pp. 155-175). Love is both one of the basic emotional concepts while also being an abstract concept which is not only difficult to conceive and express, but also which contains rich conceptual content. The conceptual metaphor is "the main way for us to understand abstract concepts and conduct abstract thinking" (Lan Chun, 1999, p. 7). Metaphors can not only help us better understand the abstract and complex emotional experience, but also help us comprehend certain aspects of love. Metaphors can represent the most typical characteristics of love that are salient for people in their common use (Karandashev, 2019, p. 11).

Conceptual metaphors of particular emotional concepts are based on culture and experience, though several unrelated languages may share conceptual metaphors, there are some metaphors in different cultures that are not exactly the same. Love is an eternal topic in human society so there are a great deal of Chinese texts and English literary texts related to love. This article adopts the conceptual metaphor theory as a framework by comparing the love metaphor in literary texts of Chinese and of English. All the expressions are taken from the texts of love poems in Chinese and in English respectively. These expressions will be analyzed in order to identify if there are similarities and differences of the love metaphor in English and of that in Chinese literary texts. 


\section{Literature Review}

Kövecses $(2000$, p. 27) states that "the concept of love is perhaps the most highly 'metaphorized' emotion concept. The first study of love metaphors can be traced back to Metaphors We Live by (Lakoff \& Johnson, 1980, p. 49). By examining a number of ordinary English expressions about love, Lakoff and Johnson (1980, p. 49). list five love metaphors in English, these love metaphors are as follows: love is a physical force, love is patient, love is madness, love is magic and love is war. Kövecses (1986, pp. 61-103) is another scholar who focuses on the study of love metaphors in order to come up with a fairly clear definition of the concept of love. Based on a great deal of conventionalized English expressions, he discovers the constitute and structure of the concept of romantic love, and he studies the love metaphor in a more detailed and comprehensive way from the central metaphor, the object of love, basic concepts, intensity, passivity and lack of control, etc.

Tissari (2006, pp. 131-174) studies the love metaphors in Shakespeare's plays, from which a list of possible love metaphors is extracted that Lakoff and Johnson (1980, p. 49) and Kövecses (1986, pp. 61-103) use in order to see if these love metaphors occur in Shakespeare's plays. The results show that the love metaphors occurring in Shakespeare's plays are shown as love is a valuable commodity and love is a force. Muhammet (2020, pp. 56-72) investigates how suffering in love is metaphorically conceptualized in Turkish via the use of natural phenomena and disasters. Based on figurative expressions in Turkish sad love songs, the study reveals that love pain/suffering is expressed through three metaphors: 1) love pain/suffering is a natural phenomenon, 2) love pain/suffering is like having natural disasters, 3) the lover's body is a landscape. The study makes a distinction between the three metaphors above about body parts and the well-known notion that love is a natural force.

There are abundant words that denote love in many world languages (Karandashev, 2017, p. 3). "Some metaphors are potential universal and the fact that some metaphors vary cross-culturally" (Kövecses, 2005, p. 292). Some cross-cultural studies have shown that different languages share some basic metaphors in conceptualizing love, while some metaphors that are frequent in one language may not appear in another language. Mashak et al. (2012, pp. 200-207) conducted research on basic emotional metaphors in English and Persian literary texts, the result indicates that the concept of love in English and Persian is conceptualized through several conceptual metaphors, which are nutrient metaphors, container metaphors and unity metaphors. Aksan and Kantar (2008, pp. 262-291) investigate love metaphors from the cross-cultural perspective of two typologically unrelated languages-English and Turkish. The study identifies that although conceptual metaphors of love is a constructed object and love is an economic exchange seem to be shared both in English and Turkish, they still have subtle differences in the expressions. Besides, there are specific level abstract source domains in Turkish, which do not appear in the English data: pain/suffering, ineffability, and deadly force.

\section{Universal Love Metaphors in English and in Chinese Literary Texts}

One of the commonalities of human thinking is to employ concrete items to describe abstract ideas. Love is one of the most important human emotions, and this emotion is both complex and abstract. People often use concrete and tangible items to describe it. Based on similar life experiences, the physiological structure of human body and cognitive structures, several similar love metaphors are shared both in English and in Chinese literary texts (Note 1).

\subsection{Love is Like a Journey}

The journey metaphor elaborates the aspects of the progress, difficulties and goal of the love relationship (Kövecses, 1986, p. 7). There are such expressions both in English and in Chinese literary texts that metaphorize love as a journey.

(1) O Mistress mine where are you roaming?

O stay and hear, your true love's coming,

That can sing both high and low.

Trip no further pretty sweeting.

Journeys end in lovers' meeting,

Every wise man's son doth know.

- O Mistress Mine, Where Are You Roaming William Shakespeare

(2) 行行重行行, 与君生别离。 相去万余里, 各在天一涯。

道路阻且长, 会面可安知。 


\section{- 行行重行行 佚名 (Note 2)}

You always keeping traveling and never stops, which makes us apart. There are thousands of miles between you and me, and I am on the side of the sky, you are on the other side of the sky. It's a long and dangerous journey. When can we meet each other?

\section{- Walking Again and Again Anonymous}

Example (1) talks about a man who is persuading his lover to stop trying to find love in other places and to live in the present, and he wants to tell his lover that he is there right now. "Journeys end in lovers meeting" meaning that maybe they will turn out to love each other, and the man compares their love to a journey. In Example (2), “重行行” means “walking again and again”, “生别离” means “separate while still alive”, the meaning of the first line is that the woman's lover keeps traveling and her lover has been away for a long time. Chinese characters “道路” means "journey" in English. There are thousands of miles between them and it is difficult to meet each other. The journey is so dangerous and far away, and she doesn't know when they can meet again. In this example, the woman compares her lover to a traveler.

\subsection{Love is a Unity (of two complementary parts)}

"Amongst the various ways of conceptualizing love, the model according to which love is a unity of two complementary parts is perhaps central" (Kövecses, 1986, p. 62). There are some typical expressions both in English and in Chinese, such as: we are made for each other (我们是天生的一对), they are inseparable (他们密 不可分), she is my better half (她是我的另一半). “The unity metaphor suggests perfect harmony, an idyllic state" (Kövecses, 1986, p. 63). If we consider love as the unity of two parts, then we can also conceive of love as a bond, or attachment between the two parts.

(3) Where can we find two better hemispheres,

Without sharp north, without declining west?

Whatever dies, was not mixed equally;

If our two loves be one, or, thou and I

Love so alike, that none do slacken, none can die.

- The Good Morrow John Donne (Note 3)

(4) 始欲识郎时, 两心望如一。

理丝入残机, 何悟不成疋。

$$
\text { - 子夜歌·始欲识郎时 南朝乐府 (Note 4) }
$$

When we meet each other for the first time, I hope that our heart can be joined together. If our love can be woven into the loom, there is no need to worry about we are not a couple.

$$
\text { - Zi-ye's Love Song }
$$

In Example (3), the speaker uses "two better hemispheres" to indicate that he and his lover are two complementary parts. "If our two loves be one, or, thou and I" emphasizes the idea that the two lovers are a single entity, their relationship will not be cold or about to end, it is warm and rising. Example (4) describes that the woman hopes that she and her lover can be a unity, then they will lead a happy life forever. However, she does not expect her lover to be unfaithful, leaving her with an incomplete dream. We all know that people who love each other should be together, and their relationship should be harmony and intimate, then they can be a unity, which is the common wish for all lovers.

\subsection{Love is a Flower}

We are familiar with the process of a flower opening being similar to that of the growth of love. When it comes to flowers, we might think of some common expressions such as beautiful, tender, charming and sweet-smelling so that all of these feelings can make us joyful. Chinese and English literary texts often use flowers to refer to their lovers or to the beloved.

(5) O my love is like a red, red rose

That's newly sprung in June.

$$
\text { - A Red Rose Robert Burns (Note 5) }
$$

(6) 长相思, 在长安, 络纬秋啼金井阑。微霜凄凄等色寒。 
孤灯不明思欲绝，卷帷望月长空叹，美人如花隔云端!

$$
\text { 一 长相思 李白 (Note 6) }
$$

I yearn for one, Who's in Chang'an. In autumn crickets wail beside the golden rail; The first frost, although light, invades the bed's delight. My lonely lamp burns dull, of longing I would die; Rolling up screens to view the moon, in vain I sigh. My flower-like beauty is high. Up as clouds in the sky.

$$
\text { - Lovesickness Li Bai (Note 7) }
$$

（7）美人一何丽，颜若芙蓉花。

$$
\text { 一美女篇 傅玄 (Note 8) }
$$

(The beauty is as beautiful as Hibiscus Mutabilis Linn)

$$
\text { - Beauty Fu Xuan }
$$

In example (5), the speaker compares his lover with that of a "a red rose" to intensify his deep feeling for her, he adores her beauty and expresses his deep love for her, with the red rose being a symbol of his love. “如花似玉” (as pretty as a flower) and “花容月貌” (fair as a flower and beautiful as the moon) are common idioms in Chinese, which literally mean that women are as beautiful as flowers, and that flowers can be used to describe a woman's outstanding beauty. Example (6) describes the speaker missing his lover day and night, and his feeling of missing her is more intense when he sees the lonely lamp in his house and the moon outside. His lover is as beautiful as a flower, but the beauty is so far away that they cannot meet. In example (7), the speaker compares his lover to “芙蓉花” (Hibiscus Mutabilis Linn). In Chinese culture, the hibiscus is often used to describe a woman's beauty. Besides hibiscus, the lotus, peach flower, and pear flower also are considered as symbols of purity and nobility to refer to the purity and beauty of the lover. From the above analysis, we can see that the beauty of a flower can be metaphorized into the beauty of a lover both in English and in Chinese languages.

(8) Love is like a flower, it must flower and fade;

If it doesn't fade, it is not a flower.

It's either an artificial rag blossom, or an immortelle, for the cemetery.

$$
\text { - The Mess of Love D.H. Lawrence (Note 9) }
$$

（9）花红易衰似郎意，水流无限似浓愁。

$$
\text { 一 竹枝词 刘禹锡 (Note 10) }
$$

Red flowers fade fast as my gallant's love; The river like my sorrow will ever flow.

\section{- Bamboo Branch Songs Liu Yuxi (Note 11)}

Although flowers are beautiful when they bloom, they will fade eventually. In example (8), the speaker is pained at the loss of his lover, so he says that "love is like a flower, it must bloom and fade", which means that a love relationship can grow vigorously and wither gradually. Besides, the speaker also states that a flower that does not wither is not a true flower, just like the final end of a passionate love relationship where love is fading. The similar expression can also be found in (9), “花红易衰” means blooming flowers always wither easily. The woman compares the lover's love for her to flowers. His love for her used to be sweet, but the love droops soon. The blossom of love always withers. These sentences describe that the woman is exquisitely painful because she is disappointed in the love relationship. Both English and Chinese writers use the ultimate fate of flowers to express their disappointment in love.

\subsection{Love is Illness}

Suffering is a common topic regarding to romantic love (Karandashev, 2017, p. 4). Love is not sweet all the time, and it also comes with sadness and pain. The journey of love will not be smooth, and two people in love may experience some suffering and pain; when they truly lose their love, maybe their heart will be dead, just like a person who has no soul; when they can't meet their lovers, the intensity of the feeling of missing each other may make people get lovesickness. All the unpleasant experiences in a love relationship may make people pine away, feel uncomfortable, and have lack of an appetite, etc., which are the similar to the feelings people have when they become ill.

(10) I ne'er was struck before that hour.

And stole my heart away complete. 
My face turned pale as deadly pale,

My legs refused to walk away,

- First Love John Clare (Note 12)

(11) 衣带渐宽终不悔, 为伊消得人憔悴。

My clothes hang loose on my emaciated body. But regrets I have none, it is because of her.

- Butterflies in Love with Flower Liu Yong (Note 14)

Example (10) describes the sudden love that the speaker feels for a woman whom he is seeing for the first time. When he sees the woman, he feels his heart being stolen away from him, his face grows faint, he cannot control his feelings so that he is unable to move. His affection for her is so strong that he cannot control his body - as if he were ill. Example (11) describes the speaker as being sad and gaunt because he misses his lover so much. Because of lovesickness, the speaker gradually pines away, his face becomes withered, and his spirit droops, yet he never feels remorse about these changes even though he is tortured by the pain. $\mathrm{He}$ is unswervingly loyal to his love.

\subsection{Love is Fire/Heat}

The fire metaphor is perhaps the most important metaphor concerning the intensity of love. And since intensity plays a very marked role in the way we think of love, the fire metaphor has a central role in the concept of love as a whole (Kövecses, 1986, p. 86). Fire is often used to conceptualize the intensity of love.

(12) My love is like to ice, and I to fire;

How comes it then that this her cold so great

Is not dissolved through my so hot desire.

$\cdots$

Is not allayed by her heart-frozen cold,

But that I burn much more in boiling sweat,

And feel my flames augmented manifold?

- My Love Is Like to Ice Edmund Spenser (Note 15)

(13) 春草醉春烟, 深闺人独眠。 积恨颜将老, 相思心欲燃。

$$
\text { 一闺思诗范云 (Note 16) }
$$

The spring scenery is very charming, and I am sad to sleep alone in the boudoir. Thinking of I am getting old, and my missing to my lover is as intense as flame. I have dreamed of being reunited with my lover many times.

\section{- Poem of boudoir repining's Fan Yun}

In Example (12), the speaker states that his lover is like ice and he is like fire, and they are different people. The speaker asks how his lover's "cold so great" is not "dissolved through" his "so hot desire", but his "heat" is not impacted by "her heart-frozen cold." Although she turns him down, his fire of loving her is not extinguished. These lines indicate the speaker's deep love for his lover, and the speaker thinks that his love for her is the same as "fire". In example (13), although the scenery in spring is beautiful, the woman is not in the mood to enjoy the beautiful scenery. Her missing for her lover like a fire burning which makes her painful. From the above analysis, we can conclude that "intensity of love/intensity of missing lover correspond to fire/flame" in English and Chinese literary texts.

\subsection{Love is Part of Human Body}

"Metaphors are coherent with certain physical aspects of the human body" (Kövecses, 2005, p. 285). People often employ important organs of the human body to express love both in Chinese and also in English literary texts. These organs, such as "heart", "eyes", the "liver", and "intestine" are to our body in a similar way as what love is to our spirit. Among these organs, "heart" is the most popular one both in Chinese and in English literary texts.

(14) Or bid me love, and I will give 
A loving heart to thee.

- To Anthea Who May Command Him and Thing Robert Herrick (Note 17)

(15) When we two parted

In silence and tears.

Half broken-hearted

To sever the years.

（16）忆君心似西江水，日夜东流无歇时。

- When We Two Parted George Byron (Note 18)

一 江陵愁望有寄 鱼玄机 (Note 19)

Thinking of you, my heart is like the torrent of the river, flowing eastward day and night never to rest in slumber.

- Look out from the riverside Yu Xuanji (Note 20)

（17）相思似海深，旧事如天远。

泪滴千千万万行, 更使人、愁肠断。

一下算子·答施 乐婉 (Note 21)

My love is deep as the sea high; The past is far away as the sky. The thousand streams of tears I shed make me heart-broken and half dead.

- Song of Divination In Reply to Her Love Luo Wan (Note 22)

Example (14) the man uses "loving heart" to express his feeling for his lover. The "heart" is the symbol of "love". Example (15) describes the parting of two people who are in love thus making the speaker "broken-hearted". In a love relationship, "broken-hearted" refers to someone who is sad and upset because of being disappointed in love. Chinese literary texts also use the "heart" to indicate the physiological effects of love. In example (16), “忆君心” (heart of love) indicates the woman's missing of her husband. The woman has been expecting her husband to return, but he does not. Her missing for him is like a river that never stops. Example (17) expresses the pain of parting from the lover. The lovesickness after parting is as deep and as endless as the sea, the beautiful past is as distant as the horizon. The woman wants to cherish the last moment that they are together, but she is so sad that she cannot stop crying. The literal meaning of “愁肠断” is that someone's intestine is broken, here it has the same meaning as "heartbroken". In English literary texts, "heart" is an important metaphor for love. However, in Chinese literature, besides heart, Chinese people also use "intestine" to express the pain caused by love.

\section{Unique Metaphors in English and in Chinese Literary Texts}

A cultural unique conceptual metaphor is one that has a culturally unique source domain for the same target domain in this article. According to Kövecses (2005, pp. 231-258), different experience and different cognitive preferences or styles can lead to different metaphors across languages and cultures. There are several distinct causes that produce differential experience and hence different metaphors, including physical environment, social context, cultural context, communicative situation, social history, and social concerns and interests (ibid). The interpretation of love varies and depends on the different cultural contexts in which people live. Different cultures have produced different ways of thinking which have resulted in the concept of love metaphors with national or culture-specific characteristics.

\subsection{Unique Love Metaphors in English Literary Texts}

\subsubsection{The Object of Love is a Deity}

The special significance of the deity metaphor lies in the fact that it brings to light several of the emotional concepts associated with love; in particular, the concepts of respect, admiration, sacrifice and enthusiasm, these are integral parts of love (Kövecses, 1986, p. 72). Some words such as worship and idolize indicate that the object of love receives more love than he or she deserves. Due to the influence of the ancient mythologies of the Greeks and Romans. English culture tends to compare the lover to a deity.

(18) Innocent is the heart's devotion

With which I worship thine. 
(19) When I love her in admiration

I find myself feeling an overwhelming sensation

In awe of the beauty of one of God's creations

Competing for her heart in the mists of my utter desperation

Our love, nothing more than sheer imagination

- Love in Admiration Kenneth Davis (Note 24)

In Example (18), "worship" indicates undue respect to the object of love, the speaker loves the girl so deeply that he is willing to be devoted to her, which is similar to that of a priest seeing himself being dedicated to the service of God - thus devotion is seen as another element of love. In Example (19), "admiration" is a part of love, and to admire someone also means to respect that person. The speaker is attracted to the girl, and he is so deeply in love with her, that he cannot extricate himself from it.

\subsubsection{The Object of Love is a Valuable Object}

"Valuable" means that something is important or worth a lot of money. When applied to love, the expression indicates that the object of love is treasured and valued by someone. When the valuable object is employed in a love relationship, it indicates that lovers are attached to the person they love.

(20) O Mary dear, that you were here

With your brown eyes bright and clear.

And your sweet voice, like a bird

..

Mary dear, come to me soon,

I am not well whilst thou art far

As sunset to the sphered moon.

As twilight to the western star.

\section{- To Mary Percy Bysshe Shelley (Note 25)}

(21) I prize thy love more than whole mines of gold

Or all the riches that the East doth hold.

- To my Dear and Loving Husband Anne Bradstreet (Note 26)

In Example (20), the speaker calls Mary "dear", which shows that Mary is loved by and is important to him. In addition, he compares his lover to the "sunset" and the "twilight". The literal meaning of these lines is that there is no "sphered moon" without "sunset" and there is no "star" without "twilight", so we can see that Mary is so valuable and necessary to him. Example (21) describes the passionate love between the speaker and her husband. The speaker describes her love as pure and redemptive. The speaker values her husband's love more than a gold mine or all the riches that are in the east. She stresses the value and pleasure of her love for her husband, she believes that her love is the most valuable thing in the world.

\subsubsection{The Object of Love is Food}

Love is an indispensable emotion for human beings, just like food is also indispensable for us. In English culture, delicious and sweet food can be used to describe the lover who is charming and attractive.

(22) And a spirit in my feet

Hath led me-who knows how?

To thy chamber window, Sweet!

\section{- India Serenad Percy Bysshe Shelley (Note 27)}

In Example (22), the speaker has been dreaming of his "sweet", and he calls his lover "sweet". "Sweet" refers to the food that has a pleasant taste, containing a lot of sugar or honey. English speaking people often use some food words such as "sweet", "honey", "sweetheart" and "sugar" to call their lovers, which indicates the pleasant and sweet feeling attributed to their lovers. 


\subsubsection{Love is War}

Love is one of the most important emotions for human beings. It is connected to all other emotions and experiences. To some degree, the experience of war is similar to that experience of attracting a lover. The War metaphor is a common metaphor in English literary texts.

(23) And so I won my Genevieve,

My bright and beauteous Bride.

- Love Samuel Taylor Coleridge (Note 28)

In Example (23), a woman named Genevieve, is the beloved of the speaker who takes a lot of time to woo her. Fortunately, their story has a happy ending. The speaker uses the word "win" to tell others that he is able to win her and take her as his bride. As we all know, the literal meaning of "win" is to be the victor in war or to get something as a result of battle which indicates that someone wins the heart of the lover through his unremitting efforts.

\subsection{Unique Love Metaphors in Chinese Literary Texts}

Chinese traditional culture advocates implicit euphemism, especially in expressing love. Implicit expression is an important characteristic of ancient Chinese love poems, and poet tend to be more indirect and implicit towards love (Gao Yuan, 2011, p. 57). Therefore, influenced by this cultural model, when expressing love, people use more indirect ways to express love.

\subsubsection{Love is the Moon}

The word "moon" is "月" in Chinese. In Chinese culture, the moon was not an ordinary celestial body from the beginning. It carries profound primitive cultural information and embodies the deep feelings of life and aesthetics of ancient Chinese people. The moon is the spirit of universe in people's minds, and is also the favorite object of writers and poets (Ouyang Wenping, 2016, p. 210). For thousands of years, the moon has brought endless sentimentality and warmth as well as endless hope and nostalgia to poets and writers. Therefore, the moon has become the best vehicle for Chinese writers to express their emotions.

(24) 离人无语月无声, 明月有光人有情。

别后相思人似月，云间水上到层城。

\section{一 明月夜留别 李治 (Note 29)}

At the moment of parting, we are as silent as the moon. At this time, the moonlight spreads over the earth, and our hearts are full of tenderness like moonlight. After parting, I am like the moonlight shining from the south to the north, and my feelings of missing you can trace to any place.

$$
\text { - Parting on a Moonlit Night Li Ye }
$$

(25) 携手看花深径, 扶肩待月斜廊。

$$
\text { 一西江月·携手看花深径 贺铸 (Note 30) }
$$

Strolling along the path and enjoying flowers hand in hand. Leaning against the inclined corridor, siting side by side waiting for the moon.

\section{- The Moon over the West River He Zhu}

In Example (24), the woman's feeling of missing her lover will take her to any place similar to the moon which shines everywhere - whether that is at the end of the Earth or at the sky palace. According to “人似月” (I'm like the moon) of this poem, we see that the woman compares herself to the moon. The moon rises day after day and year after year. The woman uses the moon to explain how she misses her lover every day and every night. Example (25) describes two lovers who are enjoying the flowers in a colorful garden. The night is quiet and cool. They sit side by side waiting for the moon. Chinese people often use “花前月下 (stay in front of flowering shrubs and under the pure moon)" to indicate romantic love. The combination of the moon and flowers is a symbol of love between men and women. From this example, we can see that the moon indicates romantic love.

\subsubsection{Love is an Agricultural Product}

In ancient times, China was a vast agricultural country. Agriculture, being especially important to the lives of people, affected their way of thinking which was reflected in Chinese literary works. As a result, people's expression of love was also closely related to agricultural activities or agricultural products (Zhang Dong, 2014, pp. 24-27). Another agricultural product affecting Chinese literary works was silk which has had a long history 
in China. The Chinese character, “丝 (silk)" has the same pronunciation as the word “思 (miss)". Love is frequently conceptualized as “丝” (silk), “䖯” (silkworm), and “桑叶” (mulberry leaf) in many literary texts. The metaphor of the spring silkworm spinning silk has been used in many literary works to describe people who are faithful to their love.

（26）春蚕不应老, 昼夜常怀丝。何惜微躯尽, 缠绵自有时。

$$
\text { 一作虫丝佚名 (Note 31) }
$$

Spring silkworms spit silk day and night and never stop until they turn into chrysalis.

$$
\text { - Producing silk Anonymity }
$$

（27）相见时难别亦难，东风无力百花残。

春蜆到死丝方尽, 蜡炬成灰泪始干。

$$
\text { 一 无题 李商隐 (Note 32) }
$$

It's difficult for us to meet and hard to part. The east wind is too weak to revive flowers dead. The silkworm till its death spins from love-sick heart. The candle one when it burned has no tear to shed.

\section{- To One Unnamed Li Shangyin (Note 33)}

In Example (26), “怀丝” has the same pronunciation as “怀思 (missing the lover)”. “微躯尽” means a silkworm becomes a chrysalis when it spins its silk, and when it is applied to love, this metaphor indicates that someone is willing to pursue his or her love at the cost of his or her life. The literal meaning of “缠绵” is silk twined together, in this example, it means the lovers are linked to each other making it is difficult to separate them. The speaker compares herself to a spring silkworm by comparing the silk of the silkworm to the emotion of love. In spring, the silkworm does not stop producing silk until it dies which metaphorically suggests that the woman can sacrifice everything for her lover. The same expression can be seen in Example (27). In Example (27), the woman also compares herself to a spring silkworm because the process of spinning silk is long and painful since the silkworm cannot stop itself from doing so and during the process thereby entraps itself in its own web. The metaphor meaning is that the woman loves her lover so deeply and misses him so much that she cannot stop loving and missing him. She will be in pain throughout her whole life because she cannot be together with her lover.

"The silk of the lotus" is often used in Chinese literary texts to express one's faithful love to the beloved. There are many types of silk that are connected with each other in the lotus. Even though when the lotus root is cut, this is where there is a special moment for the silk of the lotus.

(28) 妾心藕中丝, 虽断犹相连。

$$
\text { 一去妇 孟郊 (Note 34) }
$$

My love is like the silks in the lotus root, although the lotus root is broken, the silks of the lotus root are still connected together.

$$
\text { - A woman who is forced to divorce Meng Jiao }
$$

Example (28) describes a divorced woman who misses her husband. The woman compares the missing of her husband to that of the silk of the lotus. Despite having broken up, she never stops missing him.

In addition, Chinese people use “红豆 (red beans)” to express missing. Red beans are related to lovesickness found in a love story. An ancient woman whose husband died in the border area, missed her husband so much that she cried until her death under a tree, then she turned into a red bean which sprouted the next spring. From then on, the red bean has been called the love pea seed which is quoted in literary works to express love and lovesickness. People often take it as a symbol of love.

(29) 把酒祝东风, 种出双红豆。

$$
\text { 一醉花间·春闺 吴绮 (Note 35) }
$$

Hold a wineglass and make a toast to the east wind that helps the red bean tree grow into a pair of red beans.

$$
\text { - Drunk in Flowers · Boudoir Wu Qi }
$$

Example (29) describes the warm east wind which helps the red bean tree bear many pairs of red beans. The speaker wants to thank the east wind for promoting the growth of the red beans. His purpose, thereby, is to express the best wishes for human love. 


\subsubsection{Love as Two Inseparable Items}

Since ancient times, the Chinese have been fond of pairing things where "double" has the meaning of completeness and harmony while also implying the constitution mode of symmetry. Paired items symbolize harmony and auspiciousness. The pursuit of good items in pairs comports the desire for double happiness. Animals such as the mandarin duck, butterflies, and swallows are typical items used to display double happiness. A plant such as the love tree, can also be used to express romantic love.

(30) 在天愿作比翼鸟,在地愿为连理枝。

$$
\text { 一 长恨歌白居易 (Note 36) }
$$

On high, we'd be two lovebirds flying wing to wing; On earth, two trees with branches twined from spring to spring.

$$
\text { - The Everlasting Regret Bai Juyi (Note 37) }
$$

（31）得成比目何辞死, 愿作驾春不羡仙。

$$
\text { 一 长安古意卢照邻 (Note 38) }
$$

If only I can be with you, I am willing to become flounder and confront the death fearlessly; I prefer to be mandarin duck without hesitation and quit the chance of being immortal.

$$
\text { - Ancient Changan Lu Zhaolin }
$$

（32）思为双飞燕，衔泥筑君屋。

$$
\text { 一 东城且高长 佚名 (Note 39) }
$$

We can be a pair of swallows, and build a home then live together.

$$
\text { - The High City Wall of East Luoyang Anonymous }
$$

（33）唱罢秋坟愁未歇，春丛认取双栖蝶。

$$
\text { 一 蝶恋花 纳兰性德 (Note 40) }
$$

In the autumn, I stand in front of your grave and sing a song, which can't relieve my pain. How I wish I could fly with you like two butterflies in spring.

\section{- Butterflies in Love with Flowers Nalan Xingde}

Example (30) “比翼鸟”, “a pair of loved birds” in English, are derived from an ancient Chinese legend. It was said that the bird has only one eye and one wing, and that the male bird and female bird must fly side by side thereby often being compared to loving couples. “连理枝”, “the love tree” in English, is a plant where there are two trees whose tree-trunks grow together, and therefore is often compared to that of loving couples. This line indicates that the two lovers hope that they can be as two birds flying ever together toward heaven, or as two trees with branches interlocked forever on earth because they want to be a loving couple forever.

“驾茑” means “mandarin duck” in English. “驾” refers to the “male duck”, and “莺” refers to the "female duck”. Mandarin ducks are some unique birds in China because they swim together in pairs and keep their necks interlocked when sleeping. It was said that mandarin ducks mate for life without ever choosing another mate. As such, they are considered to be a symbol of eternal love and the model of a monogamous relationship. Even if one of them dies unfortunately, the other will not find a new mate, but will spend the rest of its life lonely. “比目 鱼" means "the fish flounder" in English. The flounder has a flat body with eyes on only one side of its body. In Chinese culture, the flounder is a symbol of loyalty in love in literature. These fish swim in pairs while their eyes observe their surroundings each acting as each other's eye. They are used in literature to describe two lovers who are inseparable loving each other deeply. In Example (31), the lines mean that the speaker hopes that he can tie the knot with the woman he loves thereby assuring that he will not be afraid of death as long as they can be together like a pair of harmonious flounders, or immortal if they could be like a pair of mandarin ducks.

Example (32), “双飞燕 (a pair of swallows)” refers to a male swallow and a female swallow who always fly and nest together for their home. Chinese people believe that a pair of swallows can bring a sweet love. The speaker hopes that he and his lover could be like a pair of swallows, and that they could build a home and live together.

Example (33), “双栖蝶 (a couple butterflies)” represents two lovers. In China, there is a sad love story about butterflies where there were two lovers who died in order to pursue their love. After they died, they became two butterflies. From then on, the butterfly has been considered as a symbol of true and faithful love. Example (33) describes the speaker as having been in pain and sadness since his wife had died. The butterflies in flowers can 
fly in pairs, yet people are separated from each other by death. Therefore, he wishes he could have died with his wife and that they could have become two butterflies, so they could have flown together and could have accompanied each other.

\subsubsection{Love is a Predestined Relationship}

Deeply influenced by Buddhist culture, Chinese people believe that love or marriage is conceptualized as "(predestined relationship)".

(34) 要见无因见, 拼了终难拼

若是前生未有缘, 待重结, 来生缘。

$$
\text { 一下算子·答施 乐婉 (Note 41) }
$$

If I cannot see you again, why don't we cut to kill pain? If we are fated not to be together, let us be married in another life!

$$
\text { - Song of Divination In Reply to Her Love Luo Wan (Note 42) }
$$

Example (34) expresses the pain of parting from the woman and her lover, and also indicates her faithful love to her love. she wants to meet he but it is impossible to meet him again, even though she wants to give up their love but ultimately, she cannot give up. She believes that she cannot be with him for whole life because there is no destiny in the previous life. Although they have a predestined meeting in this life, they cannot be together. She hopes that they would get married in the afterlife.

\subsubsection{Love is Spring}

“春 (spring)" is a season full of vigor and vitality. Chinese people think that spring brings a new start when they see colorful flowers and green plants, and single people hope that they will be able to meet their love in spring. Besides, poets and writers are always full of melancholy and sorrow during this beautiful season.

（35）花朝月夜动春心，谁忍相思不相见。

$$
\text { 一 春别应令 萧绎 (Note 43) }
$$

The beautiful spring scenery moved the girl's desire for love. She missed her lover passionately, but she could not see him.

— Missing the Beloved When Seeing Spring Xiao Yi

(36) 一片春愁待酒浇。江上舟摇，楼上窝招。

秋娘渡与泰娘桥, 风又飘飘, 雨又萧萧。何日归家洗客袍?

$$
\text { - 一剪梅·舟过吴江 蒋捷 (Note 44) }
$$

Can boundless grief be drowned in spring wine? My boat tossed by waves high, Streamers of wine shop fly. The Farewell Ferry and the Beauty's Bridge would pine. Wind blows from hour to hour; Rain falls shower by shower. When may I go home to wash my old robe outworn.

- A Twig of Mume Blossoms. My Boat Passing by Southern River Jiang Jie (Note 45)

(37) 梦后楼台高锁, 酒醒窝幕低垂。

去年春恨却来时，落花人独立，微雨燕双飞。

$$
\text { 一临江仙 晏几道 (Note 46) }
$$

Awake from dreams, I find the locked tower high; Sober from wine, I see the curtain hanging low. As last year spring grief seems to grow. Amid the falling blooms alone stand I; In the fine rain a pair of swallow's fly.

\section{- Riverside Daffodils Yan Jidao (Note 47)}

The Chinese character, “春心 (spring feelings)," refers to the desire for love and admiration between men and women. In Example (35), the beautiful scenery in spring moves the girl's feelings (春心) where she passionately misses the man she loves, but is not able to see him.

“春愁” (spring sorrow), has often been used in Chinese literature to represent melancholy, pain, sadness, resentment and lovesickness. In Example (36), the man has drifted away for a long time. He passes by a place with beautiful mountains and clear rivers. Seeing the beautiful scenery in spring, he feels sad and misses his wife very much, so he is eager to return home and reunite with her. 
“春恨(spring grief)," refers to a sense of frustration caused by the passing of spring. In Example (37), when the speaker wakes up, he sees the original pavilion where his lover lived. The curtain is low and the doors and windows are closed. His lover has gone. The speaker wants to drown his sorrow, but his sorrow cannot disappear. In late spring, annoying feelings came to his mind. "Falling flowers" and "light rain" are extremely beautiful images, but in this sentence, the images mean that spring will be gone, beauty is about to disappear, which causes him to hate spring because he misses his lover so much. From Examples (36) and (37), we can see that both “春愁 (spring sorrow)” and “春恨 (spring hate)” can express the deep missing for a beloved.

\subsubsection{Love is Stone}

Stone is the most common source of themes in Chinese literature. The images of stone in literary works are always full of people's experience and feelings of real life (Meng Xiuxiang, 1996, p. 64). Due to the influence of traditional Chinese culture and concepts, when people cannot release their inner pain, they resort to stone to express their feelings and expectations.

(38) 君当作磐石，妾当作蒲苇。蒲苇韧如丝，磐石无转移。

$$
\text { — 孔雀东南飞 佚名 (Note 48) }
$$

If as the rock your love is strong, then mine as creeping vine is long. The vine's resistant as silk thread; No one could lift a rock overhead.

$$
\text { - A pair of peacocks southeast fly Anonymous (Note 49) }
$$

（39）望夫处, 江悠悠。化为石, 不回头。

山头日日风复雨。行人归来石应语。

$$
\text { 一望夫石王建 (Note 50) }
$$

Waiting for him alone. Where the river goes by. She turns into a stone.

Gazing with longing eye. Atop the hill from day to day come wind and rain;

The stone should speak to see her husband come again.

\section{- Husband-Gazing Rock Wang Jian (Note 51)}

Example (38) describes the two lovers being forced to break up due to external pressure, but the woman says the love between them is indestructible, for their love, her lover must be as firm as a rock, she will be as firm and tenacious as Pampas grass because she is full of confidence in their love.

There is a well-known legend about “望夫石 (Husband-Gazing Rock)” where a woman whose husband was away from home to join the army, stood on the north mountain, looking forward to the return of her husband. After many years later, she turned into a stone. The stone remains still, regardless of wind and rain, day and night, and has endured the wind and rain for a long time. However, the stone has not changed its original shape and still stands on the riverbank. What is written in Example (39) is that of the image and character of the stone, so by that, the speaker wants to express the woman's faithfulness and perseverance in love. She has gone through all kinds of hardship and suffering while also suffering from the pain of lovesickness. However, her love for her beloved will never change until death when she will still be looking forward to and waiting for the return of her beloved.

Based on the analysis, the correspondence can be summarized as these: the hardness of stone is the firmness of love; the unwavering stone is persistent love.

\section{Conclusion}

Love is an abstract concept; it is always an eternal theme in literature. Through the analysis of love metaphors in English and Chinese literature, the results show that there are similarities and differences between these two cultural literatures. Although English and Chinese are two unrelated languages, there are several metaphorical source domains that are used both in English and Chinese literature to conceptualize romantic love which are similar. This similarity is seen when considering that these languages express the same emotional experience and similar cognitive methods of human beings, such as "love is a journey", "love is unity" and "love is a flower". Different cultures have differences in their social expressions, customs, religious beliefs, and cognitive methods which fact produces different love metaphors and emotional expressions. This study identifies a specific level of love metaphors unique to English and Chinese cultures. The dominance of such source domains in English love metaphors shows that English speakers express a more enthusiastic and direct attitude towards love, whereas Chinese speakers tend to express a more indirect and implicit attitude towards love. 


\section{References}

Aksan, Y., \& Kantar, D. (2008). No wellness feels better than this sickness: Love metaphors from a cross-cultural perspective. Metaphor and Symbol, 23(4), 262-291. https://doi.org/10.1080/10926480802426795

Gao, Y. (2011), The change of love metaphors in love poetry. Journal of Guangdong University of Foreign Studies, 22(5), 56-63.

Karandashev, V. (2017). Romantic love in cultural contexts. Switzerland: Springer. https://doi.org/10.1007/978-3-319-42683-9

Karandashev, V. (2019). Cross-cultural perspectives on the experience and expression of love. Gewerbestrasse, Switzerland: Springer Nature. https://doi.org/10.1007/978-3-030-15020-4

Kövecses, Z. (1986). Metaphors of anger, pride and love: A lexical approach to the structure of concepts. Amsterdam, The Netherlands: John Benjamins. https://doi.org/10.1075/pb.vii.8

Kövecses, Z. (2000). Metaphor and emotion: Language, culture, and body in human feeling. New York: Cambridge University Press.

Kövecses, Z. (2005). Metaphor in culture: Universality and variation. Cambridge: Cambridge University Press. https://doi.org/10.1017/CBO9780511614408

Kövecses, Z. (2015). Where metaphors come from: Reconsidering context in metaphor. New York, NY: Oxford University Press. https://doi.org/10.1093/acprof:oso/9780190224868.001.0001

Lakoff, G. (1993). The Contemporary Theory of Metaphor. In A. Ortony (Ed.), Metaphor and thought (pp. 202251). Cambridge: Cambridge University Press. https://doi.org/10.1017/CBO9781139173865.013

Lakoff, G., \& Johnson, M. (1980). Metaphors we live by. Chicago and London: University of Chicago Press.

Lakoff, G., \& Turner, M. (1989). More than cool reason. Chicago: University of Chicago Press. https://doi.org/10.7208/chicago/9780226470986.001.0001

Lan, C. (1999). Viewing Chinese spatial metaphor from a cognitive perspective. Foreign Language Teaching and Research, 4, 8-16.

Mashak, S. et al. (2012). A Comparative Study on Basic Emotion Conceptual Metaphors in English and Persian Literary Texts. International Education Studies, 5(1), 200-207. https://doi.org/10.5539/ies.v5n1p200

Meng, X. X. (1996). The images of stone in ancient Chinese literature. Journal of Jingzhou Teachers College, 6, 64-67.

Muhammet, F. A. (2020). Metaphoric Conceptualization of Love Pain or Suffering in Turkish Songs through Natural Phenomena and Natural Disasters. Metaphor and Symbol, 35(1), 56-72. https://doi.org/10.1080/10926488.2020.1712784

Ouyang, W. (2016). The image of moon in the translation of ancient Chinese poems. Journal of Hunan Social Science, 5, 209-212.

Tissari, H. (2006c). "Is love a tender thing?" Metaphors of the word love in Shakespeare's plays. Studi Linguistici e Filologici Online, Pisa: Telematics. Journal of the Linguistics Department of the University of Pisa, 4(1), 131-174.

Zhang, D. (2014). A Study of Love Metaphors in The Book of Songs from the Perspective of Conceptual Metaphor Theory. Journal of Hunan Radio \& Television University, 59(3), 24-27.

\section{Notes}

Note 1. Elizabeth Story Donno (ed.) (2003, p. 86). London: Cambridge University Press.

Note 2. Li Yansheng. (2018, p. 30), Classics of traditional culture-ancient poetry, Chengdu: Sichuan Lexicographical Publishing House.

Note 3. John Donne (2014, p. 196). Robin Robbins (ed.). The Complete Poems of John Donne. Routledge Tailor \& Francis Group London and New York.

Note 4. Zhou Xiaotian (2017, p.326), A gale has risen and is sweeping the clouds across the sky, Chengdu: Sichuan People's Publishing House. 
Note 5. Burns, Robert (1834, pp. 274-277). Mother well, William; Hogg, James (eds.). The Works of Robert Burns. A. Fullerton. Retrieved 23 January 2018.

Note 6. Lu Su (2020, p. 108), Deer appears only at the deepest of woods: Beautiful Poems of the Tang Dynasty Translated by $\mathrm{Xu}$ Yuanchong, Wuhan: Changjiang Literature Press.

Note 7. Ibid., 6.

Note 8. Tan Guoqing (2009, p. 560), Famous Literary Selections, Beijing: Xiyuan Press.

Note 9. D. H. Lawrence (2002, p. 387). The Complete Poems of D.H. Lawrence. Hertfordshire. Wordsworth Editions Limited.

Note 10. Lu Su (2020, p. 120), Deer appears only at the deepest of woods: Beautiful Poems of the Tang Dynasty Translated by $\mathrm{Xu}$ Yuanchong, Wuhan: Changjiang Literature Press.

Note 11. Ibid., 10.

Note 12. John Betjeman, Geoffrey Taylor (1957, p. 118), English Love Poems, Faber \& Faber.

Note 13. Lu Su (2020, p. 116), Deer appears only at the deepest of woods: Beautiful Poems of the Tang Dynasty Translated by $\mathrm{Xu}$ Yuanchong, Wuhan: Changjiang Literature Press.

Note 14. Ibid., 13.

Note 15. Edmund Spenser (1996, p. 15), Richard G. Harvey (ed.) The Wascana Poetry Anthology University of Regina Press.

Note 16. Zheng Zhenduo. (2019, p. 122), General Knowledge of Chinese Literature, Chengdu: Tiandi Press.

Note 17. Boyd Montgomerie M. Ranking (1880, p. 11). The quiver of love, a collection of valentine's ancient \& modern. London: Marcus Ward \& Co.,6 7, Chandos Street and Royal Ulster Works, Belfast.

Note 18. George Gordon Byron Baron Byron (1891, p. 45). The Poetical Works of Lord Byron: With Memoir and the Original Explanatory Notes \& c. London And New York: Frederick Warne and Co.

Note 19. He Baomin (1997, p. 943), Thesaurus of Chinese Poems, Verses, Ditties and Songs, Zhengzhou: Elephant Press.

Note 20. See https://www.en84.com/dianji/shi/201105/00006423.html

Note 21. Wu Yuyang (2020, p. 60), The paper is too short to describe our feelings: Beautiful Poems of the Song Dynasty Translated by Xu Yuanchong, Wuhan: Changjiang Literature Press.

Note 22. Ibid., 21.

Note 23. Charles W. Eliot. (1938, p. 828), English Poetry, Vol. 2: From Collins to Fitzgerald (The Harvard Classics), New York: P.F. Collier \& Son.

Note 24. David D. Hall (ed.). (2004, p. 188), Puritans in the New World: A Critical Anthology. Princeton: Princeton University Press.

Note 25. Kelvin Everest and Geoffrey Matthews (ed.). (2014, p. 420), The Poems of Shelley: Volume Two: 1817

- 1819. London and New York: Routledge Taylor \& Francis Group.

Note 26. Raymond W. Gibbs, Jr, Raymond W. Gibbs, Jr. Gibbs. (1994, p. 154), The Poetics of Mind: Figurative Thought, Language, and Understanding. London: Cambridge University Press.

Note 27. John Holmes Agnew (ed.) (1899, p. 560) The Living Age. Seventh Series, Volume IV from The Beginning, Vol. 222. July, August, September. Boston: The Living Age Company.

Note 28. Henry Southgate(ed.) (1873, p. 194). The Bridal Bouquet Culled in the Garden of Literature. London: Lock Wood AXD Co.

Note 29. Feng Kecheng (1998, p. 455), Complete Works of Chinese Classics, Xining: Qinghai People's Publishing House.

Note 30. Yu Chaogang (1995, p. 113) The Selections of Chinese Song Poems, Shenyang: Liaoning Ancient Books Publishing House.

Note 31. Feng Kecheng (1998, p. 409), Complete Works of Chinese Classics, Xining: Qinghai People's Publishing House.

Note 32. Lu Su (2020, p. 122), Deer appears only at the deepest of woods: Beautiful Poems of the Tang Dynasty 
Translated by Xu Yuanchong, Wuhan: Changjiang Literature Press.

Note 33. Ibid., 32.

Note 34. Wu Jiansheng (1991, p. 738), A Dictionary of Chinese and Foreign Aphorisms, Beijing: China International Broadcasting Press.

Note 35. You Zhenzhong (1995, p. 85), The Chronicle of Qing Dynasty Poetry, Hefei: Huangshan Publishing House.

Note 36. Hengtang Tuishi (1989, p. 87), Three Hundred Tang Poems, Chengdu: Sichuan Ancient Books Publishing House.

Note 37. Translated by Xu Yuanchong, see http://bbs.tianya.cn/post-english-98951-1.shtml

Note 38. Liu Lanying (1989, p. 525), Dictionary of Ancient Chinese Literature (vol. 5), Nanning: Guangxi Education Publishing House.

Note 39. Zhang Mingfang (2001, p. 104), One Hundred Ancient Poems, Taiyuan: Shanxi Ancient Books Publishing House.

Note 40. Zhao Caijuan (2014, p. 379), Selected Readings of ancient Chinese literature, Tianjing: Nankai University Press.

Note 41. Ibid., 21.

Note 42. Ibid., 21.

Note 43. Lu Shengjiang (2018, p. 388), A Selection of Classical Chinese Poems, Hefei: Huangshan Publishing House.

Note 44. Wu Yuyang (2020, p. 100), The paper is too short to describe our feelings: Beautiful Poems of the Song Dynasty Translated by Xu Yuanchong, Wuhan: Changjiang Literature Press.

Note 45. Ibid., 44.

Note 46. Wu Yuyang (2020, p. .68), The paper is too short to describe our feelings: Beautiful Poems of the Song Dynasty Translated by Xu Yuanchong, Wuhan: Changjiang Literature Press.

Note 47. Ibid., 46.

Note 48. Xu Yuanchong (1996, p. 2), Golden Treasury of Chinese Poetry in Han, Wei and Six Dynasties, Beijing: Beijing University Press.

Note 49. Ibid., 40.

Note 50. Xu Yuanchong (2011, p. 512), 300 Tang Poems, Beijing: China Intercontinental Press.

Note 51. Xu Yuanchong (2011, p. 196), 300 Tang Poems, Beijing: China Intercontinental Press.

\section{Copyrights}

Copyright for this article is retained by the author, with first publication rights granted to the journal.

This is an open-access article distributed under the terms and conditions of the Creative Commons Attribution license (http://creativecommons.org/licenses/by/4.0/). 